\title{
ANALISIS PENDAPATAN, PERSEPSI, DAN MINAT PETANI DALAM BERUSAHATANI UBI KAYU DI KECAMATAN SUKADANA KABUPATEN LAMPUNG TIMUR
}

\author{
(The Analysis of Income, Perception, and Farmers Interest to Cassava Farming in \\ Sukadana Subdistrict, East Lampung Regency)
}

Anggelia Permata Sari, Raden Hanung Ismono, Rabiatul Adawiyah

Jurusan Agribisnis, Fakultas Pertanian, Universitas Lampung, Jl. Prof. Dr. Soemantri Brodjonegoro No. 1 Bandar Lampung 35145, e-mail : hanung.ismono@fp.unila.ac.id

\begin{abstract}
The objectives of this study are to find out the profit, the farmers' perception, the farmers' interest of industrial cassava farmers, and to analyze factors affecting of the farmers' interest for the industrial cassava. The locations of this study are chosen purposively in Sukadana and Rajabasa Batanghari Villages, Sukadana District, East Lampung Regency. The number of respondents were 64 farmers selected using simple random sampling method. The data were collected in September - October 2018. The profit is analyzed descriptively, the farmers' perception is analyzed using the Likert Scale, and the factors affecting farmers' interest are analyzed using binary logistic regression. The results of this study showed that the profit was IDR10,355,938.25 per hectare. The farmers' perception of the industrial cassava farming was easy because of its the easiness of cultivation, the reliability of market, the availability of the agricultural extension, and the fulfillment for the farmers' needs. The farmers' interest in cassava farming was low. The factors affecting the farmers' interest in cassava farming were the planting area and the price of the cassava.
\end{abstract}

Key words: agriculture, cassava farmers, interests, perception

\section{PENDAHULUAN}

Ubi kayu (Manihot utilissima) merupakan komoditas tanaman pangan di Indonesia yang menempati urutan ketiga setelah padi dan jagung (Ginting 2002). Sebagai komoditas sub-sektor tanaman pangan yang penting, ubi kayu atau singkong telah mendapat perhatian pemerintah sebagai bahan pangan potensial masa depan dalam tatanan pengembangan agribisnis dan agroindustri. Ubi kayu dibagi menjadi dua jenis yaitu ubi kayu pangan dan ubi kayu industri. Ubi kayu pangan dapat dijadikan berbagai macam olahan makanan diantaranya keripik singkong, singkong rebus, kerupuk singkong, combro, dan getuk. Ubi kayu industri dapat dijadikan sebagai bahan baku industri, seperti industri pengolahan tepung tapioka dan bahan baku bioethanol.

Provinsi Lampung merupakan sentra produksi utama ubi kayu didukung oleh iklim dan ketersediaan faktor - faktor produksi, terutama lahan, yang masih sangat luas di Lampung. Provinsi Lampung sebagai daerah penghasil ubi kayu terbesar seharusnya mampu memberikan pendapatan yang sesuai bagi petani ubi kayu. Namun, pada kenyataannya pendapatan yang diterima petani ubi kayu masih tergolong rendah. Tak jarang pula petani ubi kayu mengalami kerugiaan. Kabupaten Lampung Timur menempati posisi ketiga penghasil ubi kayu terbesar di Provinsi Lampung setelah Kabupaten Lampung Tengah dan Lampung Utara (Badan Pusat Statistik 2017).

Kurun waktu dua tahun terakhir harga jual ubi kayu rendah yakni Rp800 per Kg. Jatuhnya harga jual ubi kayu disebabkan oleh semakin terbukanya peluang impor tapioka, sehingga menyebabkan para pelaku industri makanan yang sebelumnya menggunakan bahan baku tapioka lokal beralih ke tapioka impor karena harga tapioka impor lebih murah daripada tapioka lokal. Akibatnya, terjadi penurunan permintaan tapioka yang menyebabkan terjadinya penurunan produksi tapioka pada industri-industri pengolahan tepung tapioka lokal. Hal ini tentunya akan berdampak kepada para petani ubi kayu dimana pasar utama penjualan ubi kayu tersebut adalah industri-industri pengolahan tepung tapioka lokal.

Hasil penelitian Anggraini, Hasyim, dan Situmorang (2013), menyebutkan bahwa rantai pemasaran ubi kayu di Provinsi Lampung memiliki 
dua saluran pemasaran yang hanya melibatkan dua pelaku pemasaran yaitu pedagang pengumpul dan pabrik tapioka. Pendeknya rantai pemasaran ini menyebabkan para pelaku pemasaran dapat memonopoli harga, sementara petani bertindak sebagai penerima harga (price taker). Permasalahan di atas dapat dijadikan pertimbangan bagi para petani ubi kayu, khususnya petani ubi kayu di Kabupaten Lampung Timur untuk beralih ke usahatani lainnya yang dinilai lebih menguntungkan, sehingga petani dapat memperoleh pendapatan yang lebih layak. Namun, kenyataannya petani ubi kayu masih tetap bertahan dalam berusahatani ubi kayu.

Minat petani dalam melakukan usahatani diperkirakan akibat adanya pengaruh dari karakteristik berbagai faktor. Faktor-faktor tersebut dapat berupa faktor internal yang ada dalam diri petani maupun faktor eksternal yang berasal dari luar diri petani. Karakteristik perilaku, persepsi petani dalam menjalankan usahatani berbeda-beda. Hal ini tentu akan mempengaruhi minat petani dalam menentukan usahatani yang akan dijalankan. Berdasarkan latar belakang, maka tujuan dari penelitian ini adalah menganalisis pedapatan, persepsi, minat, dan faktor-faktor yang mempengaruhi minat petani dalam berusahatani ubi kayu di Kabupaten Lampung Timur.

\section{METODE PENELITIAN}

Penelitian ini dilakukan di Desa Sukadana dan Rajabasa Batanghari Kecamatan Sukadana Kabupaten Lampung Timur yang dipilih secara sengaja (purposive) dengan pertimbangan lokasi tersebut merupakan sentra produksi ubi kayu di Kecamatan Sukadana Kabupaten Lampung Timur. Penelitian ini menggunakan metode Survei. Waktu pengambilan data dan pengolahan data dilakukan pada bulan September - Oktober 2018 melalui wawancara dengan menggunakan kuesioner.

Jenis data yang digunakan pada penelitian ini terdiri dari data primer dan data sekunder. Data primer diperoleh melalui wawancara secara langsung dengan responden menggunakan kuesioner. Data sekunder diperoleh dari dokumendokumen tertulis dari lembaga atau instansi, jurnal, skripsi, publikasi dan pustaka lain yang relevan dengan penelitian. Metode pengambilan sampel menggunakan metode acak sederhana (simple random sampling) (Arikunto 2010) diperoleh jumlah responden sebanyak 64 petani.
Menurut Soekartawi (1995), pendapatan usahatani adalah selisih antara penerimaan petani dan semua biaya produksi yang dikeluarkan oleh petani. Secara matematis untuk menghitung pendapatan usahatani dapat ditulis sebagai berikut :

$\pi=\mathrm{TR}-\mathrm{TC}$

Keterangan :

$\pi=$ Keuntungan/pendapatan

$\mathrm{TR}=$ Total revenue (total penerimaan)

$\mathrm{TC}=$ Total cost $($ total biaya)

Data hasil wawancara tentang persepsi dan faktorfaktor yang mempengaruhi minat petani dalam usahatani ubi kayu di Kecamatan Sukadana berupa data kualitatif yang dibuat skor. Data hasil skor terlebih dahulu dianalisis validitas dan realibilitas. Analisis persepsi menggunakan skala likert summated rating (SLR) dan analisis regresi logisik biner dengan program SPSS versi 24 untuk mengetahui faktor-faktor yang mempengaruhi minat petani.dalam berusahatani ubi kayu dengan model persamaan sebagai berikut :

$P_{i}=F\left(Z_{i}\right)=F\left(\alpha+\beta_{1} X_{1}+\beta_{2} X_{2}+\beta_{3} X_{3}+\beta_{4} X_{4}+\right.$

$\beta_{5} \mathrm{X}_{5}+\delta_{1} \mathrm{D}_{1}+\mathrm{e}$

Keterangan:

$\mathrm{Pi}=$ Peluang petani ubikayu untuk menetukan tingkat minat

$\mathrm{Zi} \quad=$ Peluang petani ubikayu ke-i menentukan tingkat minat,dimana :

$\mathrm{P}_{1} \quad=$ Peluang petani ubikayu untuk berada pada tingkat minat tinggi

$\mathrm{P}_{0} \quad=$ Peluang petani ubikayu untuk berada pada tingkat minat rendah

$\alpha=$ Koefisien regresi

$\beta_{1}-\beta_{5}=$ Koefisien variable bebas

$\mathrm{X}_{1} \quad=$ Luas lahan (ha)

$\mathrm{X}_{2}=$ Usia petani (tahun)

$\mathrm{X}_{3}=$ Pengalaman Berusahatani (tahun)

$\mathrm{X}_{4}=$ Tingkat Pendapatan $(\mathrm{Rp})$

$\mathrm{X}_{5} \quad=$ Jumlah anggota keluarga (orang)

$\mathrm{D}_{1}=$ Harga Komoditi, dimana $: \mathrm{D}=1$ Menarik, $\mathrm{D}=0$ Tidak menarik

$\mu \quad=$ Kesalahan Pengganggu

\section{HASIL DAN PEMBAHASAN}

\section{Karakteristik Responden}

Mayoritas usia petani berkisar antara 43 - 57 tahun $(43,75 \%)$. Hal tersebut menunjukkan bahwa usia petani termasuk dalam usia produktif (Mantra 
2004). Usia dapat mempengaruhi produktivitas kerja petani karena mempengaruhi daya kemampuan fisik dan pola pikir dalam melakukan usahatani ubi kayu. Petani yang berumur muda memiliki kemampuan fisik yang lebih baik dibandingkan petani yang berumur relatif lebih tua. Sebanyak 15,62 persen petani memiliki pekerjaan di luar usahatani ubi kayu yaitu bekerja dibengkel, supir dan buruh perusahaan berada pada kelompok usia 28 -42 tahun dan tergolong dalam kelompok usia muda yang produktif secara ekonomi. Jumlah anggota keluarga yang ditanggung oleh petani ubi kayu berkisar antara $2-3$ orang $(65,63 \%)$. Hal ini berarti sebagian besar rumah tangga responden telah sesuai dengan Norma Keluarga Kecil Bahagia dan Sejahtera (NKKBS) yang memiliki kriteria jumlah anggota keluarga ideal maksimal 4 orang. Tingkat pendidikan formal seseorang berpotensi mendukung seseorang dalam menjalankan kegiatan usahataninya. Mayoritas petani responden $(46,88 \%)$ telah menempuh pendidikan hingga jenjang Sekolah Menengah Pertama (SMP)/sederajat. Rata-rata luas lahan garapan petani responden adalah 2,54 ha termasuk dalam klasifikasi luas. Ubi kayu merupakan komoditas pokok yang banyak diusahakan petani di Kecamatan Sukadana dengan mayoritas pengalaman yang dimiliki petani 10-18 tahun $(39,06 \%)$.

\section{Usahatani Ubi Kayu}

Petani ubi kayu di Kecamatan Sukadana, Kabupaten Lampung Timur menggunakan bibit yang bervariasi. Bibit yang digunakan petani ubi kayu yaitu varietas UJ-3 (Thailand), UJ-5 (Cassesart), dan UK-2 (Buto Ijo). Harga bibit ubi kayu masih tergolong mahal dengan nilai 10.000 per ikat. Satu ikat bibit terdiri atas 40 batang dan setiap batang dapat menjadi 5 bagian stek ubi kayu. Rata-rata penggunaan bibit ubi kayu tidak sesuai dengan anjuran Balai Pengkajian Teknologi Pertanian (2008). Pada lahan 1,03 hektar rekomendasi penggunaan bibit maksimal 12.875 stek ubi kayu tetapi tetapi rata-rata petani responden menggunakan 15.000 stek ubi kayu per ha lahan. Mayoritas petani menggunakan cara tanam sistem rapat dengan jarak tanam $80 \mathrm{~cm}$ x 80 $\mathrm{cm}$ yang berpengaruh terhadap penggunaan bibit tanaman ubi kayu dalam jumlah besar. Penggunaan bibit yang tidak sesuai anjuran akan memberikan pengaruh negatif terhadap produksi ubi kayu per hektar, dimana produktivitas ubi kayu rendah yakni sekitar 18-22 ton/ha.
Pupuk yang digunakan petani adalah pupuk kandang, Urea, TSP, KCl, NPK Phonska, dan SP36. Rata-rata untuk satu hektar lahan petani membutuhkan pupuk kandang, urea, TSP, $\mathrm{KCl}$, NPK, dan SP36 berturut-turut adalah sebanyak $353,10 \mathrm{Kg}$ per ha, $660,86 \mathrm{Kg}$ per ha, $123,42 \mathrm{Kg}$ per ha, $295,03 \mathrm{Kg}$ per ha, 469,40 $\mathrm{Kg}$ per ha dan 110,83 $\mathrm{Kg}$ per ha. Rata-rata penggunaan semua pupuk kimia dan kandang per hektar untuk tanaman ubi kayu di bawah anjuran dari Balai Pengkajian Teknologi Pertanian (2008), setiap hektar penggunaan pupuk optimal seharusnya sebanyak 5 ton pupuk kandang $+200 \mathrm{~kg}$ Urea $+150 \mathrm{~kg} \mathrm{SP36}$ $+100 \mathrm{~kg} \mathrm{KCl}$. Penggunaan obat-obatan, seperti gramason, roundup dan sidaron untuk memberantas gulma dilakukan secara kimia untuk menghemat waktu pengerjaan dan penggunaan tenaga kerja. Sementara itu, hama dan penyakit yang menyerang tanaman ubi kayu dibiarkan saja oleh petani.

Penggunaan tenaga kerja banyak berasal dari luar keluarga (LK) dengan upah per HKP Rp 70.000,00. Tenaga kerja tersebut terdiri dari tenaga pria dan wanita yang disamaratakan dalam satuan Hari Kerja Pria (HKP) dengan standar jam kerja sebanyak 8 jam kerja per hari, tetapi ada sebagian yang bekerja paruh waktu dengan jumlah hari kerja lebih banyak.

Kegiatan pemanenan pada komoditas ubi kayu dilakukan pada umbinya. Umbi dipanen dengan cara dicabut langsung batangnya. Waktu panen ubi kayu bervariasi sesuai dengan varietas yang dibudidayakan. Petani kurang memperhatikan waktu tanam, dimana biasanya mereka akan secara serentak dalam menanam ubi kayu yang akan menyebabkan waktu panen ubi kayu juga serentak, sehingga akan terjadi kelebihan produksi yang dapat berdampak pada rendahnya harga ubi kayu. Ubi kayu varietas UJ-3 (Thailand) dan UK-2 (Buto ijo) mulai dapat dipanen umbinya pada saat 6 BST (Bulan Setelah Tanam), serta ubi kayu varietas UJ-5 (Cassesart) mulai dapat dipanen umbinya pada saat 9 BST. Semakin panjang waktu panen, maka jumlah produksi umbinya akan semakin besar.

\section{Pendapatan Usahatani Ubi Kayu}

Keuntungan usahatani adalah selisih penerimaan dengan semua biaya produksi (Soekartawi 1995). Berdasarkan Tabel 1 rata-rata pendapatan usahatani ubi kayu industri di Kecamatan Sukadana, Kabupaten Lampung Timur per hektar dalam satu musim tanam berdasarkan biaya tunai 
sebesar Rp10.355.938,25. Rata-rata nisbah penerimaan usahatani ubi kayu industri dengan biaya tunai (R/C) adalah sebesar 1,90. Nilai tersebut berarti setiap Rp1.000,00 biaya yang dikeluarkan dalam usahatani ubi kayu akan diperoleh penerimaan sebesar Rp1.900,00 dengan margin keuntungan sebesar Rp900,00

\section{Persepsi Petani Terhadap Usahatani Ubi Kayu}

Persepsi petani merupakan penilaian petani terhadap usahatani ubi kayu di Kecamatan Sukadana, Kabupaten lampung Timur (Rahmat 2001). Persepsi dilihat berdasarkan indikator yaitu (1) kemudahan budidaya ubi kayu, (2) keandalan pemasaran ubi kayu, (3) ketersediaan lembaga penyuluhan, dan (4) Tingkat pemenuhan kebutuhan petani.Persepsi petani terhadap usahatani ubi kayu dapat dilihat pada Tabel 2.

Persepsi petani terhadap budidaya ubi kayu industri berada dalam klasifikasi tinggi sebesar 53,13 persen. Tingginya persepsi petani terhadap budidaya ubi kayu industri dipengaruhi oleh kemudahan dalam budidaya ubi kayu industri. Pengolahan lahan yang dimulai dari kegiatan membersihkan gulma dan tanaman liar, memberikan tambahan unsur hara dengan pupuk kandang, maupun membajak tanah, serta membuat bedengan dapat dilakukan dengan mudah didukung oleh alat-alat pertanian yang mudah didapatkan dari toko sarana pertanian. Penanaman mulai dari jarak tanam dan jumlah bibit yang harus ditanam dalam satu hektar lahan telah diketahui dengan baik oleh petani.Cara menanam ubi kayu juga dapat dilakukan dengan mudah.Pemupukan tanaman ubi kayu dapat dilakukan petani dengan mudah, dimana mereka hanya perlu menaburkan pupuk disekitar tanaman ubi kayu. Namun, pengendalian hama dan penyakit tanaman ubi kayu cukup sulit dikendalikan, karena lahan garapan petani tergolong luas dan kecepatan infeksi tanaman akan hama dan penyakit tanaman cukup tinggi. Oleh karena itu, petani memilih untuk tidak mengendalikan hama yang menyerang tanaman. Kegiatan panen mudah dilakukan, karena petani hanya perlu mencabut batang dan umbi secara sekaligus, lalu memisahkan umbi dan batangnya. Umbi ubi kayu akan dijual kepada pabrik-pabrik pengolahan tepung tapioka lokal yang ada disekitar areal lahan. Sementara itu, batangnya akan digunakan kembali untuk penanaman musim berikutnya.

Tabel 1. Rata-rata pendapatan usahatani ubi kayu petani per hektar per periode di Kecamatan Sukadana tahun 2018

\begin{tabular}{|c|c|c|c|c|}
\hline \multirow[b]{2}{*}{ Uraian } & \multicolumn{3}{|c|}{ Nilai (Rp/ha) } & \multirow[b]{2}{*}{$\begin{array}{l}\text { Rata-rata Total } \\
\quad(\mathrm{Rp} / \mathrm{ha})\end{array}$} \\
\hline & $\begin{array}{c}\text { UJ-3 } \\
\text { (Thailand) }\end{array}$ & $\begin{array}{c}\text { UJ-5 } \\
\text { (Cassesart) }\end{array}$ & Buto Ijo & \\
\hline A. Penerimaan & $20.552 .325,58$ & $24.881 .827,73$ & $20.181 .818,18$ & $21.871 .990,50$ \\
\hline \multicolumn{5}{|l|}{ B. Biaya Tunai } \\
\hline 1. Bibit Beli & $749.867,86$ & $748.424,37$ & $750.000,00$ & $749.430,74$ \\
\hline 2. Pupuk & $5.404 .035,58$ & $6.032 .940,52$ & $5.635 .909,09$ & $5.690 .961,73$ \\
\hline 3. Obat-obatan & $220.800,17$ & $227.022,06$ & $94.545,45$ & $180.789,23$ \\
\hline 4. TKLK & $2.341 .966,17$ & $2.723 .214,29$ & $2.488 .181,82$ & $2.517 .787,43$ \\
\hline 5. TKM & $1.000 .264,27$ & $997.899,16$ & $1.000 .000,00$ & $999.387,81$ \\
\hline 6. Biaya Angkut & $1.233 .139,53$ & $1.492 .909,66$ & $1.210 .909,09$ & $1.312 .319,43$ \\
\hline 7. Pajak PBB & $62.973,48$ & $69.852,94$ & $51.818,18$ & $61.548,20$ \\
\hline 8. Iuran Kelompok Tani & $4.624,74$ & $3.676,47$ & $3.181,82$ & $3.827,67$ \\
\hline D. Total Biaya Tunai & $11.017 .671,82$ & $12.295 .939,47$ & $11.234 .545,45$ & 11.516.052,25 \\
\hline \multicolumn{5}{|l|}{ E. Biaya Diperhitungkan } \\
\hline 1. TKDK & $52.149,40$ & $23.109,24$ & $18.181,82$ & $31.146,82$ \\
\hline 2. Sewa Lahan & $4.999 .119,10$ & $4.989 .495,80$ & $5.000 .000,00$ & 4.996.204,97 \\
\hline 3. Penyusutan Alat & $102.431,29$ & $141.228,99$ & $79.151,52$ & $107.603,93$ \\
\hline F. Total Biaya Diperhitungkan & $5.153 .699,79$ & $5.153 .834,03$ & $5.097 .333,33$ & $5.134 .955,72$ \\
\hline G. Biaya Total $(\mathrm{D}+\mathrm{F})$ & 16.171.371,60 & $17.449 .773,50$ & $16.331 .878,79$ & 16.651.007,97 \\
\hline I. Pendapatan Atas Biaya Tunai (A-D) & $9.534 .653,77$ & $12.585 .888,26$ & $8.947 .272,73$ & $10.355 .938,25$ \\
\hline J. Pendapatan Atas Biaya Total (A-G) & $4.380 .953,98$ & $7.432 .054,23$ & $3.849 .939,39$ & $5.220 .982,53$ \\
\hline K. R/C Atas Biaya Tunai (A/D) & 1,87 & 2,02 & 1,80 & 1,90 \\
\hline L. R/C Atas Biaya Total (A/G) & 1,27 & 1,43 & 1,24 & 1,31 \\
\hline
\end{tabular}


Persepsi petani ubi kayu industri terhadap pemasaran ubi kayu industri dalam klasifikasi tinggi $(57,81 \%)$ artinya pemasaran ubi kayu industri mudah dilakukan. Mayoritas petani menjual sendiri hasil usahatani ke perusahaanperusahaan pengolah tepung tapioka lokal. Hal ini karena tidak adanya pelaku pemasaran untuk menampung hasil panen ubi kayu, seperti pedagang pengumpul dan tengkulak.

Tidak adanya pelaku pemasaran tersebut karena banyaknya jumlah produksi petani sehingga tidak memungkinkan untuk ditampung perorangan atau lembaga. Perusahaan-perusahaan tersebut diantaranya PT Sorini Agro Asia Corporindo Tbk, Itara Rukun Santoso, PT Inti Sumber Agung Lancar, dan PT Florindo Makmur.

Persepsi petani ubi kayu industri terhadap ketersediaan lembaga penyuluhan pertanian dalam klasifikasi tinggi sebesar 57,81 persen. Hal ini menujukkan bahwa lembaga penyuluhan pertanian tersedia dengan baik dan bermanfaat bagi para petani. Hal ini terlihat dari adanya Balai Penelitian dan Pengembangan Pertanian di Kecamatan Sukdana, kelompok tani dan lembaga peminjaman modal lain, seperti bank yang membantu petani dalam mendapatkan informasi dan pinjaman modal baik secara langsung maupun tidak langsung. Lembaga penyuluhan pertanian di Kecamatan tersebut cukup aktif dalam memberikan informasi mengenai hal-hal yang berkaitan dengan usahatani ubi kayu, seperti varietas baru dan informasi terkait budidaya ubi kayu yang baik dan benar. Namun, informasi yang diberikan tidak diiringi dengan pembinaan kepada para petani, sehingga petani enggan melakukan teknik budidaya yang telah diinfomasikan.

Persepsi petani terhadap tingkat pemenuhan kebutuhan petani ubi kayu industri terletak pada klasifikasi cukup terpenuhi dengan persentase sebesar 42,19 persen, artinya kebutuhan terhadap sandang, pangan, dan papan sudah terpenuhi dengan baik. Dalam memenuhi kebutuhan seharihari, terutama untuk memenuhi kebutuhan pangan, petani ubi kayu industri melakukan kegiatan dengan caramembeli dan tidak membeli. Bahan pangan seperti minyak, gula dan garam dibeli dari pasar, toko maupun warung terdekat, selain itu bahan pangan dapat pula diperoleh tanpa perlu membeli dengan cara memproduksi pangan sendiri dari hasil memanfaatkan lahan kosong di sekitar rumah, seperti cabai dan daun singkong.

Persepsi petani ubi kayu industri terhadap usahatani ubi kayu industri dalam klasifikasi tinggi sebesar 50,00 persen yang berarti usahatani ubi kayu mudah dilakukan. Petani menilai budidaya ubi kayu industri mudah dilakukan mulai dari kegiatan pengolahan lahan hingga panen dan pasca panen yang dapat dilakukan dengan mudah.

Tabel 2. Persepsi petani terhadap usahatani ubi kayu di Kecamatan Sukadana, Kabupaten Lampung Timur

\begin{tabular}{|c|c|c|c|c|}
\hline Indikator & $\begin{array}{c}\text { Interval } \\
\text { (Skor) }\end{array}$ & Klasifikasi & $\begin{array}{c}\text { Jumlah } \\
\text { Responden } \\
\text { (Orang) }\end{array}$ & Persentase $(\%)$ \\
\hline \multirow[t]{4}{*}{ Kemudahan budidaya ubi kayu } & $22-25$ & Rendah & 9 & 14,06 \\
\hline & $26-29$ & Sedang & 21 & 32,81 \\
\hline & $30-33$ & Tinggi & 34 & 53,13 \\
\hline & Jumlah & & 64 & 100,00 \\
\hline \multirow[t]{4}{*}{ Keandalan pemasaran ubi kayu } & $5-6$ & Rendah & 3 & 4,69 \\
\hline & $7-8$ & Sedang & 24 & 37,50 \\
\hline & $9-10$ & Tinggi & 37 & 57,81 \\
\hline & Jumlah & & 64 & 100,00 \\
\hline \multirow[t]{4}{*}{ Ketersediaan lembaga penyuluhan } & $4-5$ & Rendah & 12 & 18,75 \\
\hline & $6-7$ & Sedang & 27 & 42,19 \\
\hline & $8-9$ & Tinggi & 25 & 39,06 \\
\hline & Jumlah & & 64 & 100,00 \\
\hline \multirow[t]{4}{*}{ Tingkat pemenuhan kebutuhan petani } & $4-5$ & Rendah & 12 & 18,75 \\
\hline & $6-7$ & Sedang & 27 & 42,19 \\
\hline & $8-9$ & Tinggi & 25 & 39,06 \\
\hline & Jumlah & & 64 & 100,00 \\
\hline \multirow[t]{4}{*}{ Rekapitulasi Persepsi Petani } & $64-69$ & Rendah & 15 & 23,44 \\
\hline & $70-75$ & Sedang & 17 & 26,56 \\
\hline & $76-81$ & Tinggi & 32 & 50,00 \\
\hline & Jumlah & & 64 & 100,00 \\
\hline
\end{tabular}


Pemasaran ubi kayu dapat dilakukan dengan mudah yang terlihat dari banyaknya perusahanperusahan pengolah tepung tapioka lokal yang menampung hasil produksi ubi kayu petani. Lembaga penyuluh pertanian tersedia dan bermanfaat dalam keberlangsungan usahatani ubi kayu industri. Petani juga sudah cukup dapat memenuhi kebutuhan hidupnya dengan baik. Baiknya persepsi terhadap usahatani ubi kayu industri memungkinkan usahatani ini untuk berkembang lebih baik lagi.

\section{Faktor-faktor Yang Mempengaruhi Minat Petani Terhadap Usahatani Ubi Kayu}

\section{Minat Petani Dalam Usahatani Ubi Kayu}

Minat adalah kecenderungan pada diri individu untuk tertarik atau menyenangi suatu objek (Suryabrata 1988). Minat akan mempengaruhi seseorang dalam menentukan kegiatan yang akan dilakukan. Minat terhadap suatu objek merupakan hasil dari pembelajaran yang sudah terjadi dan membantu untuk memilih kegiatan selanjutnya yang akan dilakukan (Astuti, Ismono, dan Situmorang 2013). Tingkat minat petani ubi kayu industri diukur dengan menggunakan enam indikator yang terdiri dari perasaan senang, ketertarikan, keinginan, aktivitas kelompok tani, semangat, dan lingkungan eksternal yang dikategorisasikan menjadi minat rendah dan minat tinggi Hasil kategorisasi tingkat minat petani ubi kayu dalam melakukan usahatani ubi kayu industri dapat dilihat pada Tabel 3 .

Tabel 3 menunjukkan bahwa mayoritas petani responden memiliki tingkat minat yang rendah $(59,38 \%)$ dalam melakukan usahatani ubi kayu industry di Kecamatan Sukadana, Kabupaten Lampung Timur. Rendahnya minat petani dalam berusahatani ubi kayu disebabkan oleh pendapatan usahatani yang rendah dan tidak menentu. Petani tetap memilih berusahatani ubi kayu industri karena pengalaman yang telah mereka miliki dalam bidang usahatani ubi kayu industri sudah cukup lama. Selain itu, keahlian dalam usahatani yang terbatas juga menjadi salah satu faktor penyebab petani petani tetap memilih dalam berusahatani ubi kayu industri. Keterbatasan keahlian ini karena mayoritas petani petani mendapatkan keahlian dalam berusahatani ubi kayu secara turun-temurun dari orang tua atau kerabat. Keterbatasan pendidikan dan kesempatan pekerjaan yang terdapat di lingkungan mereka juga menjadi faktor penyebab banyaknya petani yang terpaksa dalam menjalankan usahatani ubi kayu industri.

2. Faktor-faktor Yang Mempengaruhi Minat Petani Dalam Usahatani Ubi Kayu

Minat adalah sebuah aspek yang menghubungkan antara seseorang dengan pekerjaan. Minat dapat dipengaruhi oleh beberapafaktor baik dalam diri seseorang maupun dari luar diri seseorang (Hadinoto 1998). Minat petani ubi kayu industri merupakan variabel terikat (dependent) terdiri dari dua tingkatan kategori, yaitu minat rendah (0) dan minat tinggi (1). Minat petani ubi kayu dalam berusahatani ubi kayu industri dipengaruhi oleh beberapa faktor. Faktor-faktor tersebut selanjutnya disebut sebagai variabel bebas (independent), yaitu tingkat pendapatan usahatani, jumlah anggota keluarga petani, luas lahan usahatani, usia petani, pengalaman berusahatani, budidaya ubikayu industri,dan harga komoditi.

Hipotesis yang digunakan pada analisis ini diduga minat petani dalam berusahatani ubi kayu industri di Kecamatan Sukadana, Kabupaten Lampung Timur dipengaruhi oleh luas lahan $\left(\mathrm{X}_{1}\right)$, usia petani $\left(\mathrm{X}_{2}\right)$, pengalaman berusahatani $\left(\mathrm{X}_{3}\right)$, tingkat pendapatan $\left(\mathrm{X}_{4}\right)$, jumlah anggota keluarga $\left(\mathrm{X}_{5}\right)$, dan harga jual komoditas ubi kayu $\left(\mathrm{D}_{1}\right)$. Regresi logistik biner digunakan untuk menguji hipotesis tersebut dengan SPSS versi 24.

Berdasarkan Tabel 4, model persamaan hasil regresi logistik biner faktor-faktor yang mempengaruhi petani dalam berusahatani ubi kayu industri di Kecamatan Sukadana, Kabupaten Lampung Timur sebagai berikut :

$$
\begin{aligned}
Y= & -10,622-0,000 X_{1}+0,088 X_{2}+0,659 X_{3}+ \\
& 0,203 X_{4}-0,345 X_{5}+3,447 D_{1}
\end{aligned}
$$

Tabel 3. Sebaran petani berdasarkan tingkat minat petani dalam melakukan usahatani ubi kayu industri di Kecamatan Sukadana

\begin{tabular}{cccr}
\hline $\begin{array}{c}\text { Minat } \\
\text { Interval } \\
\text { (Skor) }\end{array}$ & Klasifikasi & $\begin{array}{c}\text { Jumlah } \\
\text { Petani } \\
\text { (Orang) }\end{array}$ & $\begin{array}{c}\text { Persentase } \\
(\%)\end{array}$ \\
\hline $92-121$ & Minat rendah & 38 & 59,38 \\
$122-151$ & Minat tinggi & 26 & 40,63 \\
\hline Jumlah & & 64 & 100,00 \\
\hline
\end{tabular}


Tabel 4. Hasil regresi logistik biner faktor-faktor yang mempengaruhi petani dalam berusahatani ubi kayu industri di Kecamatan Sukadana

\begin{tabular}{|c|c|c|c|c|}
\hline Variabel & B & Wald & Sig & $\begin{array}{l}\text { Odds } \\
\text { Ratio }\end{array}$ \\
\hline Luas Lahan $\left(\mathrm{X}_{1}\right)$ & $0,000^{*}$ & 6,719 & 0,010 & 1,000 \\
\hline Usia Petani $\left(\mathrm{X}_{2}\right)$ & 0,088 & 2,464 & 0,116 & 1,092 \\
\hline $\begin{array}{l}\text { Pengalaman } \\
\text { usahatani }\left(\mathrm{X}_{3}\right)\end{array}$ & $-0,659$ & 1,569 & 0,210 & 0,517 \\
\hline Pendapatan $\left(\mathrm{X}_{4}\right)$ & 0,203 & 0,528 & 0,467 & 1,225 \\
\hline $\begin{array}{l}\text { Jumlah anggota } \\
\text { keluarga }\left(\mathrm{X}_{5}\right)\end{array}$ & $-0,345$ & 1,217 & 0,270 & 0,708 \\
\hline $\begin{array}{l}\text { Harga Komoditas } \\
\left(\mathrm{D}_{1}\right)\end{array}$ & $3,447 * *$ & 16,166 & 0,000 & 31,421 \\
\hline Constant & $-10,622$ & 3,768 & 0,052 & 0,000 \\
\hline
\end{tabular}

Hasil regresi logistik biner memperlihatkan bahwa luas lahan berpengaruh nyata dan signifikan terhadap minat petani dalam berusahatani ubi kayu industri di Kecamatan Sukadana yang ditunjukkan dengan nilai odds rasio luas lahan sebesar 1,000 dan nilai signifikansi $0,000>\alpha(10 \%)$. Variabel luas lahan usahatani berpengaruh nyata terhadap minat petani dalam berusahatani ubi kayu dengan tingkat kepercayaan sebesar 90,00 persen. Petani yang memiliki luas lahan yang lebih besar, maka akan berpeluang memiliki tingkat minat dalam berusahatani ubi kayu sebesar 1 kali dibandingkan dengan petani yang memiliki luas lahan lebih sempit. Hal ini sesuai dengan hasil penelitian Panurat, Parojouw dan Loho (2014), serta Alvita, Ismono dan Kasmir (2018) dimana luas lahan usahatani sangat mempengaruhi minat, apabila luas lahan usahatani semakin luas maka minat petani untuk berusahatani semakin tinggi.

Harga komoditas berpengaruh nyata dan signifikan terhadap minat petani dalam berusahatani ubi kayu industri di Kecamatan Sukadana.Hal ini ditunjukkan dengan nilai odds rasio sebesar 31,421 dan nilai Sig. $0,000<\alpha(10 \%)$. Variabel harga komoditas berpengaruh nyata terhadap minat petani dalam berusahatani ubi kayu dengan tingkat kepercayaan sebesar 99,00 persen. Petani dengan harga jual komoditas ubi kayu yang lebih tinggi, maka akan berpeluang memiliki tingkat minat dalam berusahatani ubi kayu sebesar 31,421 kali dibandingkan dengan petani dengan harga jual komoditas ubi kayu yang lebih rendah. Hal ini sesuai dengan Muhammad, Agustono dan Wijayanto (2016) yang mengatakan bahwa harga komoditas mempengaruhi minat petani dalam melakukan usahatani.

Harga komoditas yang tinggi ditentukan dengan produk yang berkualitas. Kualitas yang baik dihasilkan oleh proses produksi yang dilakukan dengan baik (Soekartawi 1995). Penjualan hasil produksi yang berkualitas akan memperoleh penerimaan yang tinggi, sehingga petani akan termotivasi untuk menanam komoditas tersebut pada musim tanam selanjutnya. Sementara itu, apabila harga komoditas tidak menarik berarti harga komoditas tersebut rendah dipasaran yang menyebabkan petani memilih untuk berusahatani komoditas lain yang memiliki harga tinggi.

\section{KESIMPULAN}

Berdasarkan hasil penelitian maka dapat disimpulkan bahwa rata-rata pendapatan usahatani ubi kayu industri per hektar dalam satu musim tanam berdasarkan biaya tunai sebesar Rp10.355.938,25 dan nisbah penerimaan dengan biaya (R/C) tunai sebesar 1,90. Persepsi petani ubi kayu industri terhadap usahatani ubi kayu industri dalam klasifikasi tinggi berarti usahatani ubi kayu mudah dilakukan, dinilai dari kemudahan budidaya, keandalan pemasaran, ketersediaan penyuluhan dan tercukupinya kebutuhan petani. Minat petani ubi kayu dalam berusahatani ubi kayu industri di Kecamatan Sukadana berada dalam tingkat minat yang rendah. Faktor-faktor yang mempengaruhi minat petani ubi kayu dalam berusahatani ubi kayu industri di Kecamatan Sukadana adalah luas lahan dan harga komoditas ubi kayu.

\section{DAFTAR PUSTAKA}

Alvita R, Ismono RH, dan Kasmir E. 2018. Faktor-faktor yang mempengaruhi minat pemuda pedesaan dalam berusahatani padi di Kabupaten Lampung Tengah. JIIA. 30 (1):18. http://jurnal.fp.unila.ac.id/index.php/JIA /article/view/146/157. [23 Januari 2019].

Anggraini N, Hasyim AL, dan Situmorang S. 2013. Analisis efisiensi pemasaran ubi kayu di Provinsi Lampung. JIIA. 1 (1) : 8086.http://jurnal.fp.unila.ac.id/index.php/JIA/ar ticle/view/135/139 [5 November 2017].

Arikunto S. 2010. Prosedur Penelitian: Suatu Pendekatan Praktek. PT. Rineka Cipta. Jakarta.

Astuti P, Ismono RH, dan Situmorang S. 2013. Faktor-faktor penyebab rendahnya minat petani untuk menerapkan budidaya cabai 
merah ramah lingkungan di Kabupaten Lampung Selatan. JIIA. 1 (1) : 87 - 92. http://download.portalgaruda.org/article.php?a rticle $=48934 \&$ val $=4020$ [7 November 2017].

Badan Pusat Statistik. 2017. Produksi Ubi Kayu Menurut Provinsi (ton) Tahun 1993-2015. http://www.bps.go./linkTableDinamis/view/id /880 [5 November 2017].

Balai Pengkajian Teknologi Pertanian. 2008. Teknologi Budidaya Ubi Kayu. Balai

Mantra I. 2004. Filsafat Penelitian dan Metode Penelitian Sosial. Pustaka Belajar Offset. Yogyakarta.

Muhammad A, Agustono, dan Wijianto A. 2016. Faktor yang mempengaruhi minat petani dalam berusahatani padi di Kecamatan Kebakkramat Kabupaten Karanganyar. SEPA. 12 (2) : 205-213. http://agribisnis. fp.uns.ac.id/2017/03/10. [10 November 2017].

Panurat SM, Parojouw O, dan Loho AE. 2014. Faktor-faktor yang mempengaruhi minat
Pengkajian Teknologi Pertanian Lampung. Lampung.

Ginting E. 2002. Teknologi penanganan pasca panen dan pengolahan ubi kayu menjadi produk antara untuk mendukung agroindustri. Buletin Palawija. 4 (1) : 67-83. http://balit kabi.litbang.pertanian.go.id/wp-content/uploa ds/2017/03/bp_no-4_2002_03,pdf.

November 2017].

Hadinoto SR. 1998. Psikologi Perkembangan. Gajah Mada University Press. Yogyakarta. petani berusahatani padi di Desa Sendangan Kecamatan Kakas Kabupaten Minahasa. EJournal Unsrat. 1 (1) :63-70. https:// e-journal.unsrat.ac.id/index.php/cocos/article/ download/4492/4021 [12 November 2017].

Rahmat J. 2001. Psikologi Komunikasi. Srikandi. Surabaya.

Soekartawi. 1995. Analisis Usahatani. Raja Grafindo Persada. Jakarta.

Suryabrata S. 1988. Psikologi Kepribadian. PT. Raja Grafindo. Jakarta. 